821.163.41.09::821.161.1 Црњански, Милош https://doi.org/10.18485/mks_srpska_slavistika.2018.2.ch23

\author{
Предраг Ж. ПЕТРОВИЋ \\ Универзитет у Београду \\ Филолошки факултет \\ Катедра за српску књижевност са \\ јужнословенским књижевностима
}

\title{
МИЛОШ ЦРЊАНСКИ И РУСКА КЊИЖЕВНОСТ
}

\begin{abstract}
У својим есејима и разговорима Црњански често помиње руске књижевнике, првенствено Гогоља, Тургењева, Толстоја и Достојевског. У раду се испитује колико су ови руски класици утицали на обликовање прозне поетике Милоша Црњанског, од његовог првог романа Дневник о Чарнојевићу, у којем постоје броје интертекстуалне везе са руском литературом, до Романа о Лондону, где се прати судбина руског емиграната у мегалополису модерне цивилизације. Везе са руском књижевношћу нису присутне само у романима Црњанског него и у његовим путописима, понајпре у Љубави у Тоскани, вероватно кључној књизи за разумевање суматраистичке поетике. Коначно, у неколико есеја насталих у првој половини тридесетих година прошлога века, Црњански ће писати о руској књижевности након Октобарске револуције.

Кључне речи: руска књижевност, роман, поетика, историја, суматраизам, интертекстуалност, аутобиографија.
\end{abstract}

Обиман и жанровски разноврстан опус Милоша Црњанског у знаку је интензивног дијалога са српском и европском културом и књижевном традицијом. Међу многобројним ауторима чији гласови проговарају у делима Црњанског, изузетно место имају руски књижевници. Сам аутор је у неколико наврата, поготову у познијим интервјуима у којим евоцира успомене на своје литерарне почетке, говорио о снажном утиску који су на њега оставили руски романописци. Тако у једној анкети из 1962. године, говорећи о односу према великанима светске књижевности, он истиче:

„Уверен сам, међутим, да нећу погрешити, када је реч о роману, да поменем утицај руских романсијера. Имао сам тринаест година када сам, трипут узастопце, прочитао Рат и мир. Лежао сам болестан у шарлаху, али сам га читао, ноћу, и нису могли ту књигу из руку да ми отму. Тургењев је за мене највећи уметник писања романа. Његовог Руђина читао сам, и читам, увек поново.

*pedja611@yahoo.com 
А Дим сматрам за један од мајсторски компонованих романа, а незабораван, по опису људи и утицају који идеје имају на људе.

У Првом светском рату, на фронту, носио сам у џепу записе Достојевског о робијашници у Сибиру. Да сам погинуо, с том бих књигом, на грудима, био издахнуо.

Руски романсијери су већи од свих других, далеко. Те књиге су морале оставити неког трага у мени." (Crnjanski 1992:41-42)

Ти трагови су присутни у целокупном делу Милоша Црњанског, у распону од Дневника о Чарнојевићу (1921) до Романа о Лондону (1971) и могу се пратити како на експлицитном тако и на иманентнопоетичком плану, у есејима и критикама као и у фикционалној прози и путописима.

Богате интертекстуалне везе са српским и европским књижевним наслеђем суштински одређују иманентну поетику првог романа Милоша Црњанског. Читав текст премрежен је реминисценцијама на бројне ауторе, од персијског песника Хафиса, потом Шекспира, Казанове, Бранка Радичевића, Флобера до филозофа Ничеа и Бергсона. У исти мах Дневник о Чарнојевићу наговестио је низ далекосежних књижевних момената који ће пратити готово свако од ауторових каснијих прозних остварења - од теме сеоба, духовне и историјске миграције, беззавичајности модерног човека, невидљивих и судбоносних веза између људи и појава у свету, чежње за даљинама и лутањем, затим поступака лиризаицаје прозе, удвајања приповедачевог гласа и самог романескног јунака те, коначно, питање мешања жанрова или својеврсне жанровске мимикрије. Могло би се зато рећи да Дневник о Чарнојевићу има улогу „матичне ћелије” у опусу овог великог писца, дело у коме се могу препознати неки од кључних поетичких принципа и из кога се генеришу све будуће опсесивне теме. Сам Црњански ће рећи да је Роман о Лондону „затварање једног круга” започетог пре тачно пола века појавом Дневника о Чарнојевићу у коме је отворена „проблематика миграције као егзистенцијалног човековог проблема” (Црњански 1992: 196-197). Уочљиво је присуство жанровских одређења у готово свим насловима књижевних дела Милоша Црњанског, што је посебно уочљиво у именовању његовог првог и последњег романа који чине почетак и крај једног поетичког круга, не само ауторског него важног и за судбину модернизма у српској књижевности.

Питање прожимања жанрова у прози Милоша Црњанског увек је повезано са односом према аутобиографском искуству - сопственом (од Дневника о Чарнојевићу насталог на основу ауторовог личног дневника који водио за време рата, затим мемоарски интониране Итаке и коментара, потом књиге Код Хиперборејаца, која садржи елементе путописа, романа и есеја, до Романа о Лондону) и туђем (мемоари Симеона Пишчевића као документарна основа за Сеобе и Другу књигу Сеоба). Интерес за аутобиографске прозне форме као и присуство личног животног искуства представља не само једну од кључних поетичких константи књижевног дела Милоша Црњанског, већ и знатног дела прозе у двадесетом веку. Како то поводом Пруста примећује Жерар Женет, модерни роман остварује „осмозу живота и дела у оба правца, пошто животно искуство непрестано храни писање, а ово је, опет, за њега средство, инструмент духовног искуства" (Ženet 1985: 234). О могућности да се у жанровском додиру романа и аутобиографског дискурса генерише облик „новог романа” Црњански 1920. пише у предговору за Ујевићев превод Флоберовог Новембра. Вероватно најпознатији исказ из тог текста је онај да су „мемоари увек били 
најбољи део књижевности, особито кад нису дословце верни” (Црњански 1991: 257). Зато не изненађује што приповедач Дневника о Чарнојевићу често помиње различита аутобиографска дела од Казановиних Мемоара поменутог Флоберовог Новембра. Међу тим текстовима изузетно место имају и Записи из мртвог дома Фјодора Достојевског.

У тренутку док га полиција у Сегедину саслушава, главни јунак и приповедач Дневника, Петар Рајић, призива у свест једну књигу Достојевског: „После су ме тукли. О, ни то није болело. Био сам навикао да читам романе, па сам често мислио на Достојевскову Каторгу" (Црњански 1921: 6). Реч је о аутобиографски заснованом роману Записи из мртвог дома (1862) чији приповедач пролази кроз разна мучења у сибирском затвору (отуда каторга - затвор, робијашница). Међутим, поред ове асоцијативне везе, Дневник и Записи имају знатно суптилнији међусобни однос, који би могао да подсети на огледалско пресликавање. Као што се у првом роману Црњанског помиње књига Достојевског, тако се, обратно, у Записима из мртвог дома помиње одредница која суштински обликује утопијске просторе Дневника о Чарнојевићу. У једној сцени из седме главе Записа, „Нова познанства. Петров” приповедач Александар Петровић у разговору са робијашем Петровом помиње далеко, егзотично острво у јужним морима, исто оно којим је опседнут и Чарнојевић - Суматру. То је место на коме живи антиподи, људи који према народском уверењу иду наглавачке јер живе на супротној страни земљине лопте (Dostojevski 1983: 105). Поменули смо да је Црњански у више наврата помињао да је на фронту у Првом светском рату носио записе Достојевског о робијашници у Сибиру. „Да сам погинуо, са том књигом на грудима бих издахнуо.” Трагови тог читања присутни су у његовом првом роману, али као део свести књижевног јунака Петра Рајића. Утопијске визије далеких и егзотичних простора честе су у експресионистичкој лирици након Првог светског рата. Међутим, оправдана је и претпоставка да је Црњански полинежанско острво Суматру одабрао као ескапистичку утопију инспирисан управо овим помињањем у роману Достојевског. Наиме, Црњански је своју поетику првобитни назвао етеризам, да би јој у време рада на свом првом роману дао име суматраизам. Ова сложена интертекстуална прожимања између два, по времену настанка удаљена, али по аутобиографској заснованости и приповедачком поступку блиска романа, директно реализују поетичка начела суматраизма о изненадним и неочекиваним везама. Рајићев доживљај стварности битно је одређен и посредован књигама које чита и које чине да текст Дневника буде отворена интертекстуална структура. „Све је у вези и све се слива”, вели приповедач у Писмима из Париза, „парафразирајући” Чарнојевићеве исказе из романа: „Све што су чинили тврдио је да негде, далеко, на једном острву оставља траг” (Црњански 1921: 74).

Готово сви ликови у Дневнику о Чарнојевићу одређени су књигама које читају, па тако, док Петар Рајић чита Достојевског, његова супруга Маца, али и друге јунакиње, опседнута је романом Сањин руског аутора Михаила Арцибашева. Када се Рајић из рата враћа у своје банатско село, жене „би ме опет питале да ли сам читао 'Сањина', а ја бих се тргао кад би оне прошле поред мене. А оне би ме опет питале, да ли сам читао 'Сањина'; веселе и заборавне, оне су ми признавале сто малих тајни” (Црњански 1921: 25). Маца ужива у сладострашћу желећи да поред себе има мушкарца какав је јунак Арцибашевљевог романа. „Она се чудила мојој нехатности, миру и досади 
и једнако ми давала савета како да чешљам косу, па ми је и сама чешљала. А ја сам, међутим, покушавао да је обухватим и гурао сам се са њом, док би ме она одгурнула и рекла: Ах, ти си гори од Сањина” (Црњански 1921: 26). Утицај Арцибашева видан је у српској књижевности почетком двадесетих година прошлога века, поготову у експресионистичкој прози Драгише Васића и Рада Драинца (В. о томе: Вучковић 2000: 51). У ставовима главног јунака у Дневнику о Чарнојевићу може препознати нешто од Сањиновог „нихилистичког морала”, који „одриче сваку веру и смисао”, о чему је поводом превода романа Арицибашева писала Исидора Секулић 1911. године (Секулић 1977: 349), а одређени трагови постоје и на плану Рајићевих еротских авантура. Ипак, разочарани повратник из рата у роману Црњанског свакако није заговорник слободне љубави као Сањин нити има његову виталистичку енергију. Рајић се повлачи из живота у утопијске визије, сећања и, коначно, у обликовање текстуалне стварности у дневнику који води. Сањин фигурира првенствно као мушки идеал Рајићеве супруге оспеднуте чулним задовољствима - сексом и храном.

Не изненађује што се у Дневнику о Чарнојевићу, роману у којем се тако наглашено потенцирају активности читања и писања, појављује и фигура једног пасионираног читаоца романа какав је Дон Кихот. Док се Рајићев суматраистички двојник Чарнојевић карта у некој собици препуној огледала, у сцени у којој се као на филму динамично смењују збивања и ликови, изненада се на вратима појављује Шаљапин: „На вратима се указа Шаљапин, на раги, сав крив у седлу, са грдном мотком у руци и са једним разбијеним лонцем на глави, зидови се тресли од песме његове” (Црњански 1921: 83-84). Реч је о познатом руском оперском певачу Фјодору Ивановичу Шаљапину (1873-1938), који се у европским метрополама пред Први светски рат прославио улогом Дон Кихота у истоименој опери Жила Маснеа. Занимљиво је, дакле, да се један руски уметник појављује у Рајићевом сну у улози славног романескног јунака о чему се приповеда у дневничким белешкама у књижевном делу жанровски одређеном као роман, што речито говори о деликатним односима између документарног и имагинарног, сна и јаве, личности и маске, дневника и романа.

Дневникуо Чарнојевићу свакако је један од најзначајнијих српских (анти)ратних романа. Рат је је ту виђен очима појединца и представљен кроз субјективу психолошку реакацију. Светскоисторијска пустош постала је садржај индивидуалне свести, епохални слом вредности предмет је спознаје и доживљаја усамљеног јунака. „Научили смо да пијемо живот дубље но икад откад свет постоји. Ништа нема смисла, све је пропало у ове три године”, исписује Петар Рајић, „Страховито, уплашено, пажљиво ја гледам у њима живот и држим га рукама које дрхте, и гледам око себе шуме и путеве и небо” (Црњански 1921: 29). И у Дневнику, као и наредном роману Милоша Црњанског, у Сеобама, по први пут се у српској прози очитује онај процес о којем Жак Рансијер пише поводом Толстојевог приповедања у Рату и миру. Док научна историографија покушава да себе обликује трудећи се да створи појединачне фигуре као носиоце друштвеног закона и моћи, дотле књижевност „живи у процепу између разума колективне инертности и деловања појединаца који тврдоглаво сањају о бољем свету за себе и друге" (Ransijer 2008: 83). Роман успоставља истину о историји саткану од онога што сведоци или документи знају али и од онога што званичној историографији остаје непознато, од свесног деловања појединца и од несвесног закона који их повезује. 
У покушају да књижевно представи положај појединца и народа на светскоисторијској позорници у романима Сеобе (1929) и Друга књига Сеоба (1962) Црњански ће се ослонити на поетичко искуство Толстојевог Рата и мира, од паралелно компонованог ратног и мирнодопског тока радње у првим до историозофског финала у другим Сеобама. „Најмање су оба романа историјска, иако се заснивају на мемоарима тога времена и архивској грађи”, истиче Црњански у једном интервјуу 1964. године и наставља: „Историјски романи су застарели и застарела форма, а често испадају и травестије, Калигуле, Рима, Париза, Наполеона. У роману Толстоја Pam и мир најмање је важна историја" (Crnjanski 1992: 64). Уметничка визија прошлости, према Црњанском, заснива се на откривању универзалног и метафизичког смисла људске судбине у метежу историјских дешавања. Имајући у виду Рат и мир он истиче да је у својим романима желео да опише „страховиту збрку људског живота у оквиру једне веће заједнице, читавог једног народа. [...] Није мени било стало до костима, до евокације и описа прошлог, него до људске судбине у тој прошлости. А стално сам покушавао и да кажем да треба бити оптимист, у томе смислу, да је све у вези, на свету, у људском животу" (Crnjanski 1992: 46).

Управо до једне (не)очекиване књижевне везе са Толстојевим јунаком из романа Ана Карењина Црњанском је било посебно стало, али, нажалост, није успео да је реализује због дугог и тешког изгнанства проведеног у Лондону. Поред Сеоба и Друге књиге Сеоба Црњански је намеравао да на основу историографских извора напише још четири наставка и тако заокружи шестотомну романескну визију судбине српског национа на европској позорници у осамнаестом и деветнаестом веку. Трећи том требало је да се одвија у време Првог устанка и прати трагичну судбину двојице Срба из Аустрије који су се прикључили устаницима, четврта књига збивала би се револуционарне 1848. године а пета би као историјски оквир имала изгнанство кнеза Милоша и Михаила. Коначно, шести и завршни тома великих $\mathrm{Ce}$ оба приповедао би о повратку потомка породице Исакович у Србију за време српско-турског рата 1876. „Исаковичи су се населили (у мом роману) у Русији, а своје насеље звали Рајевка. Отуда, пореклом, пуковник Рајевски се, у мом завршном роману, враћа у своју земљу са руским добровољцима и гине при нападу, после битке код Шуматовца. Имате ту личност код Толстоја" (Crnjanski 1992: 80). Дакле, у завршници своје романескне епопеје Црњански је планирао да се велики смисаони и историјски круг сеоба српског национа оконча повратком и смрћу у завичају. У исти мах то би био величанствени сусрет књижевне имагинације Црњанског и Толстоја и то у личности пуковника Николаја Николајевича Рајевског (1839-1876). Он је руском писцу послужио као прототип за лик грофа Вронског, који на крају романа Ана Карењина одлази у српско-турски рат. Као што је из историје познато, пуковник Рајевски је јуначки погинуо 1. септембра 1876. у бици за Адровац, код Алексинца, на месту на којем је касније у знак сећања подигнута црква Свете Тројице. Његов деда, генерал Николај Рајевски, био је херој Отаџбинског рата против Наполеона 1812. године и овековечен је у Толстојевом роману Рат и мир. Иако Црњански није до краја реализовао своју романескну замисао о шест томова Сеоба, она свакако сведочи о изузетном значају коју је придавао руској књижевности и српско-руским историјским везама. 
Међутим, и оно што је Црњански успео да оствари од своје замисли, романи Сеобе и Друга књига Сеоба, засновано је на тематској грађи преузетој из аутобиографске књиге написне на руском, тачније рускословенском језику. У питању су, наравно, мемоари Симеона Пишчевића (1731-1797), Живот генералмајора и каваљера Симеона, сина Стефана Пишчевића, како гласи њихов краћи наслов, о којима се у нашој историографији и књижевности дуго није ништа знало. Половином двадесетих година прошлога века Црњански је у београдској Политищи, у форми биографског есеја, представио нашој јавности живот овога Србина, који је међу „оним авантуристима и официрима, који су за доба царице Јелисавете и Катарине постали ђенерали и војсковође у Русији" (Црњански 1991: 61). Захваљујући историчару и књижевнику Васи Стајићу, који му је скренуо пажњу на архивску грађу о српским сеобама у Русију у осамнаестом веку, Црњански се заинтересовао најпре за мађарски превод Пишчевићеве књиге коју је Имре Хусар у скраћеном облику објавио 1902. у илустрованом листу Vasarnapi Ujság а потом као засебно издање 1904. године. У Русији су се Пишчевићеви момоари појавили у редакцији Нила Попова 1881-82. у часопису Чтения в Обществе истории и древностей российских а потом самостално, две године касније. У преводу Светозара Матића код нас ће бити штампани тек почетком шездесетих година прошлога века, у време када и Друга књига Сеоба. Како то у својим истраживањима закључује Милорад Павић, Симеон Пишчевић је као тринаестогодишњак почео да води дневник на српском језику, у време аустријско-француског рата 1744. године, док је био писар у пуку у којем је служио његов отац Стефан а којим је командовао Вук Исакович. Дневничке белешке писаће и касније, као аустријски официр и потом након преласка у Русију 1753 , где наставља војну службу и постаје генерал. „Тек трећа, завршна редакција текста, настала око 1784. године, била је писана на оном језику којим је Пишчевић и своју другу књиги, историју Срба, спремао за штампу - некаквом руско-словенском" (Павић 2005: 124).

Тема сеоба и трагедије српског народа на просторима јужне Угарске дискретно је присутна већ у Дневнику о Чарнојевићу а своју конкретизацију добиће најпре у ауторовим есејима „О стогодишњици Јакова Игњатовића” (1922) и „Записи ђенерала Пишчевића" (1924), у којима се јасно уочава тематско и поетичко језгро будућих Сеоба. Колико су Пишчевићеви мемоари били инспиративни Црњанском, види се и по томе што их он у есеју повремено препричава, поготову збивања везана за битку код Мајнца и под тврђавом Луј, потпуно се уживљавајући у позицију очевица, прелазећи са перфекта у аорист и развијајући експресионистичку стилизацију реченице. Приметно је да је Црњански посебно осетљив за патње и страдања војника, што није изненађујуће јер је и сам био војник на фронту и о томе певао у Лирици Итаке. Док Симеон плаче уплашен за живот свога оца, један стари граничар га теши речима које Црњански овако наводи: „Плач ти ништа не помаже, учи и гледај да се навикнеш на занат војника, научи како је горак војнички хлеб и како човек стиче славу” (Црњански 1992: 62). Трагедија војника-најамника који по туђој вољи и за туђи рачун ратују биће једна од смисаоних окосница романа Сеобе. Показујући како приповедач Сеоба преузима податке, па и читаве исказе, из Пишчевићевих записа и потом их саображава са структуром романа тако да они добијају лирски набој и метафизички контекст, Новица Петковић истиче да је у мемоарској грађи Црњански 
могао наћи и онај моменат који ће суштински одредити његову романескну визију не само српске историје него и вечите човекове беззавичајности. „У самој грађи, код Пишчевића, лако је могао наћи и то да се време одигравања радње романа међу Србима у Угарској, и не само међу њима, шири и митологизује представа о Русији као обећаној земљи” (Петковић 1988: 307). Док су Суматра, у раном, и Хипербореја, у позном, стваралаштву Црњанског утопијски простори око којих се симболично окупљају визије и знамења, Русија је историјски конкретизован хронотоп среће, обећана земља која поред митских, старозаветних, обриса добија и геополитичка одређења.

Као таква, Русија се указује у Другој књизи Сеоба, у којој је сижејна веза са Пишчевићевим текстом још наглашенија. Позиција свезнајућег приповедача који се упушта у коментарисање ликова и догађаја, у дијалог са читаоцем и, коначно, у обухватну реконструкцију епохе, уз обиље интертекстуалних веза, омогућила је, за разлику од првих Сеоба, наглашеније присуство реминисценција из руске књижевности. Једна од тих веза је посебно важна за разумевање смисла људске судбине који се обликује у овом роману. У тренуцима када у Русији тоне у меланхоличну безвољност, помирен са тим да обећана земља постоји само у метафизичким просторима сна и слутње али не и у историјским и политичким димензијама овоземаљског света, Павле Исакович, Вуков посинак, у последњој глави романа, закључује да човековим животом не управљају ни Бог нити воља људска, него неке мађије, и наставља: „Живимо, плачемо, смејемо се, кад како. Свако има свој век, своју љубав, свој светли део живота, као тица која, кажу, улети из мрака у осветљну дворану и излети на другу страну у таму” (Црњански 1981: 439). Ову алегоријску слику Црњански је вероватно преузео, и дао јој нови значењски контекст у завршници Друге књиге Сеоба, из једног од својих омиљених романа - Руђина Ивана Тургењева. Настојећи да објасни смисао живота главни јунак Тургењевљевог романа посеже за северњачком причом о цару који проводећи зимску ноћ у некој брвнари види птицу што је изненада улетела. „Цар примети да је та тичица као човек на овом свету: долетела је из мрака и одлетела у мрак, после једног тренутка проведеног у топлоти на светлости" (Тургењев 1956: 39).

Везе са руском књижевношћу нису присутне само у романима Црњанског него и у његовим путописима, понајпре у Љубави у Тоскани (1930), вероватно кључној књизи за разумевање суматраистичке поетике. Непрестано прожимање историјских и имагинарних светова, успостављање веза између словенског истока и романског запада испуњава странице овога путописа, који је у знаку кретања како кроз културно наслеђе Тоскане тако и кроз текстове и поетике различитих аутора који су на том простор некада боравили. Један од њих је и Гогољ, који је у изгнанству у Италији завршио своје најзначајније дело, Мртве душе, тачније њихов први том. Суматраистички путописац Гогоља узима као једну од кључних уметничких фигура словенског света, некога ко је најбоље изразио величину и трагедију Русије и то управо онда када је био у изгнанству, далеко до отаџбине за којом је патио. Сећање на Гогоља за приповедача је важно у контексту словенског тематског круга који у Ђубави у Тоскани афирмише визију ренесансе словенских нација. Буђење словенске снаге и духовности, прожете лиризмом, страдањем и љубављу, треба да донесе препород западној Европи посрнулој након Великог рата. 
У неколико есеја насталих у првој половини тридесетих година прошлога века, у време док је боравио у Берлину као аташе за штампу, Црњански ће писати о руској књижевности након Октобарске револуције. Изразито критичан према совјетским властима, он се првенствено бави питањима односа књижевности и политике, тачније тежње да се уметност насилно стави у службу бољшевичке пропаганде и комунистичке идеологије. У есеју „Смех Валентина Катајева” (1930) Црњански прави јасну разлику између револуције у руској књижевности, засноване на новим изражајним поступцима и преиспитивању традиције у делима Белог, Блока, Хлебњикова, Замјатина или Пастернака, од тенденција совјетских власти да књижевност промовише бољшевичку револуцију и идеализује живот у социјалистичком друштву. Међутим, тај тип ангажоване литературе доживео је неуспех.

\footnotetext{
„Тако је бољшевизам, годинама, обасипао Запад и једном новом, својом књижевношћу, што је патетично славила, улепшавала и крила оно што се у Русији догађало.

Досадна, громопуцателна књижевност бољшевика, била је тако наивно намештена да није имала успеха, у иностранству, а што је значајније, ни у Русији.

Нико није хтео да чита ту тенденциозну књижевност Совјета, те хваљене и награђиване славопојке и списанија радничке диктатуре, химне колективних песника совјетском режиму” (Црњански 1991: 315).
}

Црњански примећује да већ од краја двадесетих година нове власти допуштају појаву књига које се критичке односе према друштвеној стварности а нека од тих дела доживљавају велики успех у Европи, попут Бабељеве Црвене коюице или Пиљњакове Голе године. Највећу пажњу Црњански посвећује роману Распикуће (Растратчики) писца Валентина Катајева, који, на трагу Гогољеве прозе, даје гротескну, карикатуралну слику корумпираног чиновничког апарата у совјетској држави. Позивајући се на Иљу Еренбурга, Црњански истиче да Октобарска револуција није изродила велику књижевност, попут рецимо буржоаске револуције у Француској, и да се од нове генерације писаца очекује да превазилазећи банални политички ангажман изгради нову поетику која ће доказати да „Русија не припада једном фанатичном и крволочном политичком систему, већ човечанству и, пре свега, Славенству” (Црњански 1991: 318).

Питању односа књижевности и политике Црњански ће се враћати и касније, али са знатно ублаженом антикомунистичком реториком. У поменутој анкети из 1962. године у којој са дивљењем говори о руским класицима, он се осврће на одлуку Нобеловог комитета да награди Бориса Пастернака, оцењујући да она није произашла из естетских колико из политичких разлога. Западу је, сматра Црњански, Пастернак потребан само као комунистички јеретик, као неко ко би био критичар режима, док тај исти капиталистички свет не види да се његова култура урушава и да је пред налетом нових медија који нуде баналне садржаје, књига већ на издисају. „Док се певају химне Пастернаку на Западу, ситуација литерата постаје у капиталистичким земљама све више буфонерија, којој је допринео и ужасни пораст баналности на филму и на телевизији. Има земаља у којима књига умире” (Crnjanski 1991: 43). Ако Пастернака, вероватно, није превише ценио, Црњански је у неколико наврата врло похвално говорио о Јевгенију Јевтушенку. Поредећи га са Мајаковским, по активизму, Црњански је првенствено фасциниран Јевтушенковом појавом, наступом, начином на који казује своју поезију и тако привлачи читаоце. „Направио 
је чудо у Немачкој. Зато што уме да прави покрете, да занесе, да придобије публику. Ја верујем у његову искреност" (Crnjanski 1991: 43).

Ако је почетак модернизма у српској књижевности обележен појавом Дневника $o$ Чарнојевићу, онда је његов завршетак, почетком седамдесетих година прошлога века, у знаку Романа о Лондону. Одисејевска фигура изгнаника, присутна у свим делима Црњанског, сада је изведена на космополитску сцену модерног мегалополиса да лута без наде да ће се икада вратити у отаџбину. На често постављано питање зашто је за јунака овога романа одабрао баш једног Руса, Црњански је дао одговор који најбоље изражава његов однос према трагичном искуству руског народа у двадесетом столећу, обележеном толиким насилним егзодусима народа и појединаца.

„Мој јунак је морао бити Рус. Његова земља је највећа - њихова трагедија је највећа. Руска емиграција је права емиграција. Аристократска. Али руска емиграција слабо је стајала материјално. У књизи се види како су припадници чувених фамилија морали да зарађују лебац радећи као продавци старина, дактилографи итд. Такви руски емигранти били су погодни да покрију оно што сам желео да кажем" (Crnjanski 1992: 183).

Такав је главни јунак романа, некадашњи кнез Николај Рјепнин, чији су преци били чувени још у доба Наполеновог похода на Русију. Након лутања Европом, у таласу емиграната расејаних после Октобарске револуције, Ријепнин и његова супруга Нађа стижу у Лондону где у „астрономском конгломерату” у чију мрежу је ухваћено четрнаест милиона душа отпочиње прича о „судару два света, и судару између једног човека и једне огромне вароши” (Црњански 2004: 19).

Као што у Вавилону модерног доба одјекују различити језици, тако су и у самој наративној структури романа уписане многе алузије и цитати из светске књижевности. Поетичку самосвест о писању романа приповедач испољава већ у првим реченицама, у којима вели да се сви романописци слажу да је свет у којем живимо нека врста велике, чудновате позорнице на којој свако неко време игра своју улогу и потом силази са ње да се више никада не врати. Међутим, увод Романа о Лондону дискретно призива у читалачку свест још један чувени романескни почетак: „Quintilian каже да, за познавање човечанства, није потребно знати цело човечанство. Доста је упознати, добро, и једну фамилију” (Црњански 2004: 9). Овако уведена тема породице могла би садржати алузију на знамениту реченицу којом опочиње Толстојева Ана Карењина. Несрећна судбина Рјепнинове породице, која симболично репрезентује несрећу људи у савременом добу, биће тема књиге Црњанског.

У напору да преживи у једном привидно либералном а заправо врло негостољубивом свету, који га доживљава као туђинца, Рјепнин се повремено присећа Русије, од топлих зима на Криму до чудесних вртова Петерхова и ноћних улица Санкт Петербурга. Призиваће у свест и стихове њему омиљених руских песника. Размишљајући о самоубиству као једином достојанственом излазу из овога света, Рјепнин у једном тренутку шапуће стихове песника из деветнаестога века Николаја Некрасова, упућујући их Нађи: „Утешитсја жена, и друга лучшиј друг забудет. Утешиће се жена и друга ће и друг заборавити” (Црњански 2004: 39). У Енглеску је овај брачни пар донео само једну књигу, збирку Пушкинових стихова. Сећајући се петроградских ноћи, Рјепнину се чини да „су те ноћи, и сада, тамо, као што су биле у његово доба. Светле, румене, са прозрачним сумраком, који је био дан и остаје дан, и у ноћи, и поново се претвара у дан. Бљеск безлуниј - каже Пушкин” (Црњан- 
ски 2005: 286). Такве литературом посредоване слике пратиће главног јунака све до његовог силаска са позорнице живота. Тиме се симболично затвара поетички круг лутања и изгнанстава у романима Милоша Црњанског, који је у великој мери у знаку утопијског, историјског и меланхоличног доживљаја Русије - од жудње Вука Исковича и развејане илузије Павла Исаковича до поетских визија Николаја Рјепнина.

Пишући о великом руском песнику Јесењину, Црњански је овако представио његове последње дане уочи самоубиства:

„Оставив бољшевике, оставив уопште политику, муж играчице Исидоре Данкан, песник Јесењин, пропадајући, банчећи по Москви, пред самоубиством, син сељака, и сам сељак, плачући је викао: Не треба ми рај, дајте ми само моју Русију" (Црњански 1991: 317).

Јунак последњег романа Милоша Црњанског Јесењинов је тихи, трагични сапутник.

\section{Извори}

Тургењев И. Руђин. Прев. З. Велимировић. Нови Сад: Матица српска,1956.

Црњански М. Дневник о Чарнојевићу. Београд: Свесловенска књижарница, 1921. Црњански М. Друга књига Сеоба. Београд: Нолит, 1981.

Црњански М. Есеји и прикази. Нови Сад: Књижевна заједница, 1991.

Црњански М. Роман о Лондону. Београд: Завод за уџбенике, 2004.

Crnjanski M. Ispunio sam svoju sudbinu. Priredio Z. Avaramović. Beograd: BIGZ, 1992. Dostojevski F. Zapisi iz mrtvog doma. Prev. M. Babović. Beograd: Rad, 1983.

\section{Лuтература}

Вучковић Р. Српска авангардна проза. Београд: Откровење, 2000.

Павић М. Роман као држава и други огледи. Београд: Плато, 2005.

Петковић Н. Два српска романа. Београд: Народна књига, 1988.

Секулић И. Из страних књижевности. Књига II. Београд: Вук Караџић, 1977.

Ženet Ž. „Pitanje pisanja.” Prev. M. Vuković. Treći program, br. 103/104, 1985.

Ransijer Ž. Politika književnosti. Prev. M. Drča. Novi Sad: Adresa, 2008. 
Предраг Ж. Петрович

\section{МИЛОШ ЦРНЯНСКИЙ И РУССКАЯ ЛИТЕРАТУРА}

\section{Резюме}

В работе исследуется вопрос, насколько русские классики, Гоголь, Тургенев, Толстой и Достоевский, влияли на формирование поэтики романа Милоша Црнянского. Уже в первом романе автора, Дневник о Чарноевиче (1921), существует множество интертекстуальных связей с русской литературой. В Переселении (1929) и Второй книге переселения (1962) наблюдаются влияния романов Толстого, в то время как в Романе о Лондоне (1971) повествуется о судьбе русского эмигранта в современном городе. Связи с русской литературой присутствуют не только в романах Црнянского, но и в его путевых заметках, в первую очередь в Любви в Тоскано, вероятно, ключевой книге для понимания поэтики суматраизма. Наконец, в нескольких эссе, созданных в первой половине 30 -х годов прошлого века, Црнянский пишет о русской литературе после Октябрьской революции.

Ключевые слова: русская литература, роман, поэтика, история, суматраизм, интертекстуальность, автобиография. 